\title{
Tocilizumab Treatment Effect on Iron Homeostasis in Severe COVID-19 Patients
}

\author{
Dmitri Guz ${ }^{\mathrm{a}}$ Anat Gafter-Gvilia Nirit Lev ${ }^{\mathrm{b}}$ Gal Sahaf Levin ${ }^{\mathrm{c}}$ Shaul Lev ${ }^{\mathrm{c}}$ \\ ${ }^{a}$ Department of Medicine A, Beilinson Hospital, Rabin Medical Center, Petah-Tikva, Israel and Sackler Faculty of \\ Medicine, Tel Aviv University, Tel Aviv, Israel; ${ }^{b}$ Department of Neurology, Meir Medical Center, Kfar Saba, Israel and \\ Sackler Faculty of Medicine, Tel Aviv University, Tel Aviv, Israel; Intensive Care Unit, Rabin Medical Center, \\ Petah- Tikva, Israel and Sackler Faculty of Medicine, Tel Aviv University, Tel Aviv, Israel
}

\section{Keywords}

COVID-19 - Anemia · Iron · Tocilizumab

\begin{abstract}
Background: Tocilizumab has been proposed as an effective treatment for severe COVID-19. We aimed to investigate whether tocilizumab administration is associated with increased availability of serum iron which may possibly be associated with adverse effects on clinical outcomes. Methods: We performed an observational, retrospective cohort study. We included adults, who were hospitalized in ICU with the diagnosis of severe COVID-19 infection eligible for tocilizumab treatment. Laboratory data including serum iron, ferritin, transferrin saturation, hemoglobin, and C-reactive protein levels of all patients were collected shortly before and $24 \mathrm{~h}, 48 \mathrm{~h}$, and $72 \mathrm{~h}$ after tocilizumab administration. Results: During the study period, 15 patients fulfilled the inclusion criteria and were eligible to receive tocilizumab treatment. Tocilizumab therapy was associated with a prominent increase in serum iron and transferrin saturation levels $(26 \pm 13$ $\mu \mathrm{g} / \mathrm{dL}$ and $15 \pm 8 \%$ before treatment and $79 \pm 32 \mu \mathrm{g} / \mathrm{dL}$ and $41 \pm 15 \% 72 \mathrm{~h}$ after treatment, respectively, $p<0.001$ ) and decrease in serum ferritin levels $(1,921 \pm 2,071 \mathrm{ng} / \mathrm{mL}$ before
\end{abstract} Conclusion: Treatment of severe COVID-19 patients with tocilizumab is associated with a profound increase in serum iron and ferritin saturation levels along with a decrease in ferritin levels. This may represent an undesirable side effect that may potentiate viral replication.

(c) 2022 S. Karger AG, Basel

\section{Introduction}

Severe acute respiratory syndrome coronavirus 2 (SARS-CoV-2), an enveloped nonsegmented positivesense RNA virus, is the causal agent of the COVID-19 worldwide pandemic outbreak [1]. Clinical presentation of COVID-19 is heterogenous and ranges from asymptomatic or mildly affected patients with flu-like symptoms to life-threatening hyperinflammatory syndrome characterized by fulminant hypercytokinemia (also called cytokine storm) with a profile similar to that seen in hemophagocytic lymphohistiocytosis and ensuing multiorgan failure and acute respiratory distress syndrome $[2,3]$. Pro-inflammatory cytokines, mainly IL-6, are associated with decreased plasma iron concentration [4]. Since iron

Correspondence to:

Dmitri Guz, guz.dima@gmail.com 
is an essential element for many fundamental physiological processes including viral replication, iron deprivation during infections may serve as a protective mechanism against bacterial and viral infections $[5,6]$.

Tocilizumab, a monoclonal antibody directed against the interleukin- 6 receptor, has been proposed as potential therapy for COVID-19 by mitigating the cytokine storm syndrome associated with severe COVID-19 [7-17]. However, the efficacy of tocilizumab's therapy is not clear [18-22]. A recently published randomized, double-blind, placebo-controlled trial included 243 patients did not provide support that tocilizumab is an effective treatment for preventing intubation or death in moderately ill hospitalized patients with COVID-19 [23].

The explanation for the failure of tocilizumab to affect the clinical outcome in recent reports, despite the strong pathophysiological basis for its potential beneficial effect is not clear. We hypothesize that the inconclusive efficacy of treatment with tocilizumab may be partially explained by its influence on iron metabolism. Tocilizumab administration has been previously associated with decreased levels of hepcidin and ferritin alongside with increase in total iron-binding capacity (TIBC) and hemoglobin in patients with Castelman's disease and rheumatic arthritis [24-28].

The clinical significance of the increase in serum iron levels after treatment with tocilizumab is not clear but may represent an increase in labile iron, which may potentially propagate reactive oxygen species [29] generation and potentiate pathogen replication, which is an undesirable side effect of any anti-inflammatory therapy, given during an infectious episode.

We therefore aimed to assess the effect on iron levels in patients treated with tocilizumab. To the best of our knowledge, this is the first study investigating the effect of tocilizumab on iron release and levels in acutely infected COVID-19 patients.

\section{Methods}

We performed a single-center, observational, retrospective cohort study conducted at Hasharon Campus, Rabin Medical Center, university affiliated tertiary hospital, in Petah- Tikva, Israel. Electronic records of all consecutive adult patients ( $\geq 18$ years) hospitalized in ICU in our center during the COVID-19 pandemic between April 7, 2020, and July 1, 2020, with the diagnosis of severe COVID-19 infection requiring administration of tocilizumab were identified daily and reviewed by the study coordinators.

Diagnosis of COVID-19 was made according to CDC diagnostic criteria using authorized nucleic acid or antigen detection assays [30]. Tocilizumab was administered to all patients considered

Tocilizumab Effect on Iron Homeostasis in COVID-19 with hyperinflammatory state according to the following criteria: C-reactive protein (CRP) $>90 \mathrm{mg} / \mathrm{L}$, ferritin $>500 \mathrm{ng} / \mathrm{dL}$, and interferon gamma-induced protein $10>1,000 \mathrm{pg} / \mathrm{mL}$. All ICU patients considered as hyperinflammatory were administered a total dose of $800 \mathrm{mg}$ tocilizumab, given in 2 separate doses of $400 \mathrm{mg}$, $12 \mathrm{~h}$ apart.

All patients given tocilizumab were treated with methylprednisolone $(1.5 \mathrm{mg} / \mathrm{kg}$ divided into 3 doses $)$ or equivalent dosing of another corticosteroid. Additionally, patients also received antiviral therapy that was based on combinations of hydroxychloroquine, azithromycin, zinc, and lopinavir/ritonavir at the discretion of the infectious disease consultant and was discussed daily.

Laboratory data including serum iron, serum ferritin, transferrin saturation, hemoglobin, and CRP of all patients were collected at hospital admission, shortly before tocilizumab administration and $24 \mathrm{~h}, 48 \mathrm{~h}$, and $72 \mathrm{~h}$ after tocilizumab administration.

\section{Statistical Analysis}

The analysis was performed using the IBM SPSS statistics 26; IBM Corporation, Armonk, NY, USA. In order to assess the change in measured laboratory levels before and $24 \mathrm{~h}, 48 \mathrm{~h}$, and 72 $\mathrm{h}$ after tocilizumab administration, we used repeated measures ANOVA test with Bonferroni correction method. To test the assumption of sphericity, Mauchly's Test was implemented (null hypothesis is rejected at $p<0.05$ ). In case of violation of sphericity assumption Greenhouse-Geisser test was used. We reported $F$-statistic from a repeated measures ANOVA.

\section{Results}

During the study period from April 7, 2020, and July 1, 2020, 132 consecutive patients were hospitalized with the diagnosis of COVID-19 in our hospital. Of them, 52 were hospitalized in ICU and 15 fulfilled the inclusion criteria and were eligible to receive tocilizumab treatment.

Median age was 76 years (IQR 47-90). Twenty percent of patients were female $(3 / 15)$ and $80 \%$ were ventilated $(12 / 15)$.

The median duration of hospitalization was 18 days (IQR 17-23). The median duration of mechanical ventilation was 16 days (IQR 11-17). Three (20\%) patients died.

Before treatment, $80 \%(12 / 15)$ of our patients had low transferrin saturation $(<20 \%)$ with mean of $15 \pm 8 \%$ and $93 \%(14 / 50)$ had low levels of serum iron $(<50 \mu \mathrm{g} / \mathrm{dL})$ with mean of $26 \pm 13 \mu \mathrm{g} / \mathrm{dL}$.

All 15 patients had increased CRP levels prior tocilizumab treatment with mean levels of $25 \pm 11 \mathrm{mg} / \mathrm{dL}$. Tocilizumab therapy was associated with a significant gradual increase in mean serum iron levels from $26 \mu \mathrm{g} / \mathrm{dL}$ (SD \pm 13 ) shortly before therapy up to $79 \mu \mathrm{g} / \mathrm{dL}(\mathrm{SD} \pm 32) 72$ $\mathrm{h}$ after therapy $(F(3,42)=28, p \leq 0.001)$ (Fig. 1). 
Fig. 1. Serum iron levels before and after tocilizumab administration.

Fig. 2. Serum transferrin saturation levels before and after tocilizumab administration.
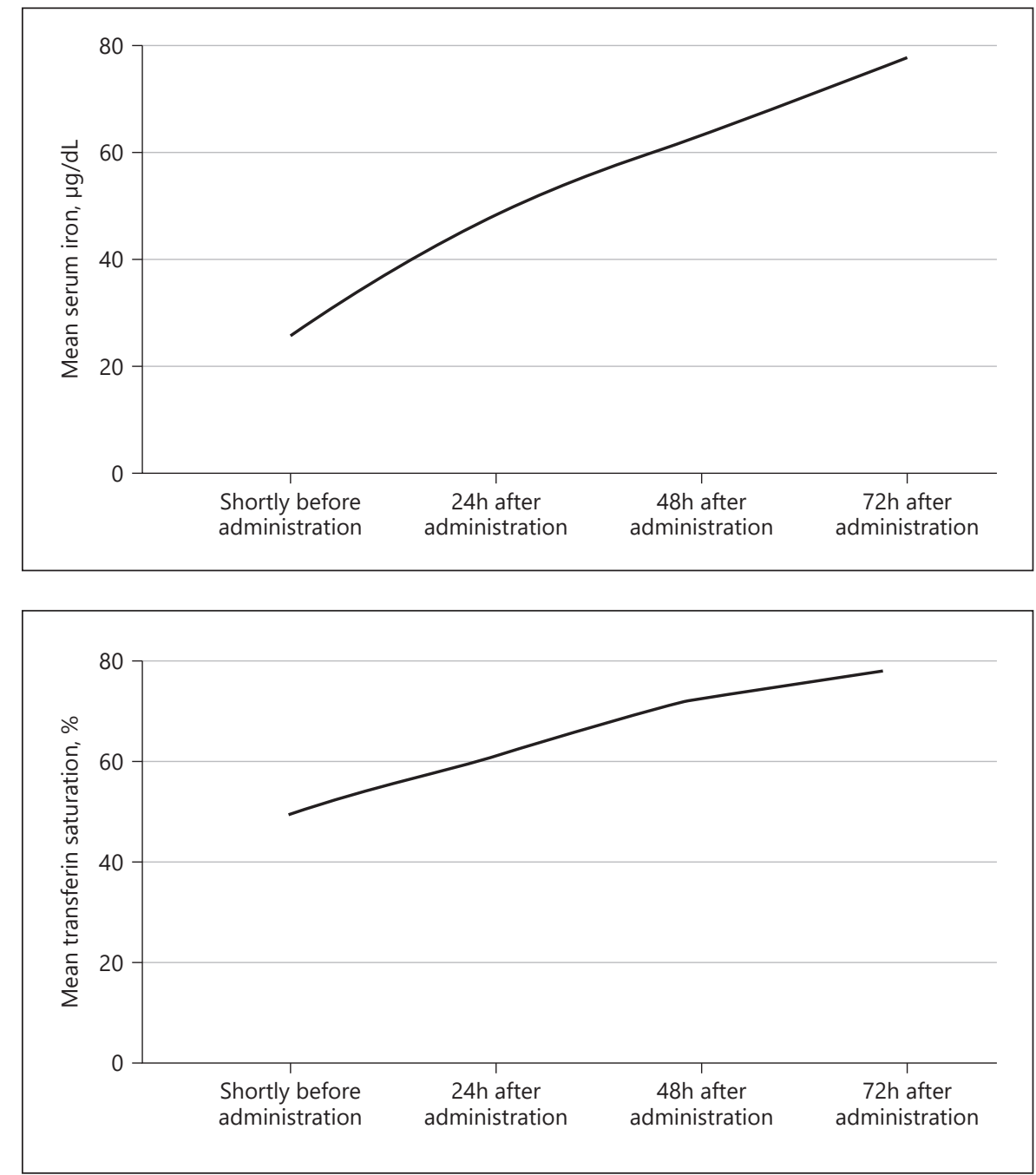

A gradual and significant increase was also observed in mean serum transferrin saturation levels shortly before therapy (15\%, SD \pm 8$)$ and $24 \mathrm{~h}(33 \%, \mathrm{SD} \pm 17), 48 \mathrm{~h}(39 \%$, $\mathrm{SD} \pm 15)$, and $72 \mathrm{~h}(41 \%, \mathrm{SD} \pm 15)$ after drug administration $(F(3,42)=21, p \geq 0.001)$ (Fig. 2).

Additionally, we observed a significant decrease in measured mean ferritin levels after tocilizumab administration, from $1,921 \mathrm{ng} / \mathrm{mL}(\mathrm{SD} \pm 2,071)$ shortly before treatment down to $1,258 \mathrm{ng} / \mathrm{mL}(\mathrm{SD} \pm 1,140) 72 \mathrm{~h}$ after treatment $(F(1,16)=5.4, p=0.027)$.

A significant decrease was also measured in mean CRP levels after administration of first tocilizumab dose (25 \pm $11 \mathrm{mg} / \mathrm{dL}$ shortly before treatment, $21 \pm 10 \mathrm{mg} / \mathrm{dL}$ after $24 \mathrm{~h}, 11 \pm 5 \mathrm{mg} / \mathrm{dL}$ after $48 \mathrm{~h}$ and $5 \pm 2 \mathrm{mg} / \mathrm{dL}$ after $72 \mathrm{~h}$, $F(1.4,20.6)=54.4, p \leq 0.001)$. No significant change in measured mean hemoglobin levels were observed before and after tocilizumab therapy $(11.4 \pm 1.6$ shortly before treatment, $10.9 \pm 1.324 \mathrm{~h}$ after treatment, $11.4 \pm 148 \mathrm{~h}$ after treatment and $11.2 \pm 1.4572 \mathrm{~h}$ after treatment, $F(3,42)=2.2, p=0.098)($ Table 1$)$.

\section{Discussion}

Results of our retrospective analysis suggest that treatment of severe COVID-19 with tocilizumab is associated with rapid and persistent increase in serum iron and transferrin saturation levels. In all of our patients, serum iron levels increased by up to 6 folds, and transferrin saturation levels were increased up to 7.5 folds during $72 \mathrm{~h}$ following treatment. Moreover, in $87 \%$ of our patients, tocilizumab had an immediate and profound effect on decreasing ferritin levels. We believe that this observation reflects the rise of free serum iron levels secondary to tocilizumab therapy. 
Table 1. Mean values and repeated measures ANOVA of laboratory measurements shortly before treatment, $24 \mathrm{~h}, 48 \mathrm{~h}$, and $72 \mathrm{~h}$ after tocilizumab administration

\begin{tabular}{llllll}
\hline & Shortly before therapy & After treatment $24 \mathrm{~h}$ & After treatment $48 \mathrm{~h}$ & After treatment $72 \mathrm{~h}$ & $F$ test, $p$ value \\
\hline Serum iron levels, $\mu \mathrm{g} / \mathrm{dL}$ & $26 \pm 13$ & $51 \pm 26$ & $66 \pm 31$ & $79 \pm 32$ & $F(3,42)=28, p<0.001$ \\
Serum ferritin levels, $\mathrm{ng} / \mathrm{mL}$ & $1,921 \pm 2,071$ & $1,876 \pm 1,944$ & $1,742 \pm 1,779$ & $1,258 \pm 1,140$ & $F(1,16)=5.4, p=0.027$ \\
Transferrin saturation, $\%$ & $15 \pm 8$ & $33 \pm 17$ & $39 \pm 15$ & $41 \pm 15$ & $F(3,42)=21, p<0.001$ \\
Serum transferrin, $\mathrm{mg} / \mathrm{dL}$ & $131 \pm 36$ & $119 \pm 31$ & $127 \pm 31$ & $142 \pm 31$ & $F(3,36)=10.5, p<0.001$ \\
Hemoglobin, $\mathrm{g} / \mathrm{dL}$ & $11.4 \pm 1.6$ & $10.9 \pm 1.3$ & $11.4 \pm 1.4$ & $11.2 \pm 1.45$ & $F(3,42)=2.2, p=0.098$ \\
CRP, $\mathrm{mg} / \mathrm{dL}$ & $25 \pm 11$ & $21 \pm 10$ & $11 \pm 5$ & $5 \pm 2$ & $F(1.4,20.6)=54.4, p<0.001$ \\
\hline
\end{tabular}

The direct upregulation of pro-inflammatory cytokines observed in patients with severe COVID-19, particularly IL-6 is well associated with increased levels of hepcidin, ferritin, and haptoglobin [4, 5, 29, 31]. Hepcidin leads to a decrease in intestinal iron absorption and decreased iron mobilization from macrophage reticuloendothelial stores. Ferritin in turn scavenges free iron and enables its sequestration in the reticuloendothelial stores and in this way prevents iron availability for invading pathogens [32]. This leads to functional iron deficiency, defined as normal or increased total body iron stores which are unavailable for incorporation into erythroid precursors for erythropoiesis [33, 34]. Indeed, results of our study are in line with this pathophysiologic basis and the vast majority of patients in our cohort had low serum iron levels and decreased transferrin saturation levels at presentation.

On the one hand, the altogether effect of hemoglobinopathy and iron dysmetabolism may seriously harm the host by compromising the capacity of erythrocytes to perform oxygen transport leading to subsequent hypoxia and inducing hyperferritinemia-related tissue alterations [29]. On the other hand, iron plays a key role in many fundamental biological processes including DNA/RNA synthesis and ATP generation necessary for viral replication [35]. Iron overload in patients with infection of hepatitis $\mathrm{B} / \mathrm{C}$ viruses has been associated with poor prognosis $[36,37]$. Thus, iron depletion may possibly have a marked beneficial antiviral effect.

Tocilizumab, an anti-interleukin 6 receptor antibody is approved for treatment of various rheumatic diseases, such as rheumatoid arthritis as well as other conditions including Castleman's disease and cytokine release syndrome [38]. Based on its anticytokine effect and subsequent attenuation of the hyperactivated immune response tocilizumab has been proposed as a potential treatment for COVID-19 by several open-label trials and nonrandomized case series [7-14, 16, 39]. A recently pub- lished meta-analysis by the WHO Rapid Evidence Appraisal for COVID-19 Therapies (REACT) Working Group evaluated the efficacy of IL6 inhibitors for the treatment of COVID-19 in reducing mortality at 28 days. As a result of the positive outcomes of this study, different expert and governmental guideline groups (WHO, NIH, IDSA) recommend tocilizumab in the treatment of COVID-19 [40].

However, there are growing evidence that the role of tocilizumab in COVID-19 therapy is inconclusive [1822]. A recently published randomized, double-blind, placebo-controlled trial failed to demonstrate beneficial effect of tocilizumab treatment for preventing intubation or death in moderately ill hospitalized patients with COVID-19 [23]. This study included 243 patients. The hazard ratio for intubation or death in the tocilizumab group as compared with the placebo group was 0.83 (95\% confidence interval $[\mathrm{CI}], 0.38-1.81 ; p=0.64)$. The reason for the lack of tocilizumab beneficial effect on clinical outcome despite the strong theoretical pathophysiological basis is unclear. We propose that a potential explanation lays in the effect of tocilizumab on iron hemostasis.

The beneficial effects of tocilizumab on anemia have been previously described in several rheumatologic and inflammatory diseases [24-28, 41-43]. These reports are in line with our results suggesting increased availability of free serum iron after tocilizumab administration. The effect of tocilizumab on iron metabolism is thought to be mediated by two possible mechanisms: hepcidin suppression by blocking IL- 6 effect [43] and by increased erythropoietin signaling. The erythropoietin receptor and IL6R complex share the JAK-STAT signaling pathway and excessive IL-6 signaling induces expression of intracellular factors that inhibit the JAK-STAT pathway [44]. Hence, tocilizumab treatment may result in increased erythropoietin signaling and hematopoiesis.

The relevance of the rapid increment in iron levels following tocilizumab treatment observed in our patients 
might be associated with reactive oxygen species generation and tissue damage. Moreover, in many pathogens including viruses, replication can be influenced by iron [45], and iron chelation has been shown in vitro to inhibit viral proliferation [46, 47]. Dalamaga et al. [48] hypothesized that iron chelator, particularly deferoxamine, may possess beneficial immunomodulatory and antiviral actions against SARS-CoV-2. The authors suggested that higher iron levels may promote the course of viral infections and development of acute respiratory distress syndrome and pulmonary fibrosis. They also speculated that iron chelators might decrease SARS-CoV-2 replication via decreasing iron availability which plays an important role in viral replication. In a recent letter to the editor, Abobaker [49] suggested that deferoxamine could be beneficial in adjunction with antiviral drugs to treat COVID-19. In addition, deferoxamine has been shown to decrease the level of IL- 6 and endothelial inflammation in vitro, which could reduce the severity of COVID-19 [50]. If that is the case, then anti-inflammatory medication as tocilizumab given too early in the disease course, may potentiate possibly viral replication through release of iron from activated macrophages and may potentially have adverse effects on clinical outcomes.

However, Garrick and Ghio [51] suggested that iron chelation treatment might actually exacerbate cytokine storm and may harm patients with COVID-19. The coronavirus is an RNA virus, with its replication relying on a RNA duplex intermediate. Such viruses do not need iron to replicate their genome unlike DNA or retroviruses, so iron withholding could be counterproductive and part of the "cytokine storm."

To the best to our knowledge, this is the first report evaluating the effect of tocilizumab therapy on iron metabolism in severe COVID-19 patients. The major limitation of our study is the small sample size used for the analyses and the retrospective nature.

Additional limitation is the lack of a control group and the possibility of cofounding results due to other concomitant therapy and to the disease itself. Moreover, patients included in this study received drugs that are no longer used for the treatment of COVID-19. However, these drugs are not known to effect iron hemostasis.

\section{Conclusions}

Tocilizumab had an immediate and profound effect on iron and ferritin levels in severe COVID-19 patients. This observation reflects the increase in availability of serum

iron level following tocilizumab treatment. This response was sustained for at least $72 \mathrm{~h}$ after drug administration and may reflect a possible relationship between tocilizumab and iron levels in COVID-19 patients.

\section{Statement of Ethics}

The study was a retrospective analysis and data were derived from patient charts. Therefore, informed consent was not required. The study was approved by the institutional research Ethics Committee of the Rabin Medical Center (Approval No. 025720-RMC).

\section{Conflict of Interest Statement}

There are no conflicts of interest.

\section{Funding Sources}

This study has not been sponsored.

\section{Author Contributions}

All authors contributed to the final version of the manuscript, provided critical feedback, and processed the experimental data.

\section{Data Availability Statement}

All data generated or analyzed during this study are included in this article online supplementary material files (for all online suppl. material, see www.karger.com/doi/10.1159/000522307) (online suppl. Table 1).

References
1 Harapan H, Itoh N, Yufika A, Winardi W, Keam S, Te H, et al. Coronavirus disease 2019 (COVID-19): a literature review. J Infect Public Health. 2020 May;13:667-73.

2 Mehta P, McAuley DF, Brown M, Sanchez E, Tattersall RS, Manson JJ, et al. COVID-19: consider cytokine storm syndromes and immunosuppression. Lancet. 2020 Mar 28;395: 1033-4.

3 Bassetti M, Giacobbe DR, Aliberti S, Barisione E, Centanni S, De Rosa FG, et al. Balancing evidence and frontline experience in the early phases of the COVID-19 pandemic: current position of the Italian Society of Anti-infective Therapy (SITA) and the Italian Society of Pulmonology (SIP). Clin Microbiol Infect. 2020 Jul;26:880-94. 
4 Nemeth E, Rivera S, Gabayan V, Keller C, Taudorf S, Pedersen BK, et al. IL-6 mediates hypoferremia of inflammation by inducing the synthesis of the iron regulatory hormone hepcidin. J Clin Invest. 2004 May;113:12716.

5 Liu W, Zhang S, Nekhai S, Liu S. Depriving iron supply to the virus represents a promising adjuvant therapeutic against viral survival. Curr Clin Microbiol Rep. 2020 Apr 20;7: $1-7$.

6 Cassat JE, Skaar EP. Iron in infection and immunity. Cell Host Microbe. 2013 May 15;13: 509-19.

7 Guaraldi G, Meschiari M, Cozzi-Lepri A, Milic J, Tonelli R, Menozzi M, et al. Tocilizumab in patients with severe COVID-19: a retrospective cohort study. Lancet Rheumatol. 2020 Aug;2:e474-84.

$8 \mathrm{Xu} \mathrm{X,} \mathrm{Han} \mathrm{M,} \mathrm{Li} \mathrm{T,} \mathrm{Sun} \mathrm{W,} \mathrm{Wang} \mathrm{D,} \mathrm{Fu} \mathrm{B,} \mathrm{et}$ al. Effective treatment of severe COVID-19 patients with tocilizumab. Proc Natl Acad Sci USA. 2020 May 19;117:10970-5.

9 Campins L, Boixeda R, Perez-Cordon L, Aranega R, Lopera C, Force L. Early tocilizumab treatment could improve survival among COVID-19 patients. Clin Exp Rheumatol. 2020 Jun;38:578.

10 Rossotti R, Travi G, Ughi N, Corradin M, Baiguera C, Fumagalli R, et al. Safety and efficacy of anti-il6-receptor tocilizumab use in severe and critical patients affected by coronavirus disease 2019: a comparative analysis. J Infect. 2020 Jul 8;81:e11-7.

11 Somers EC, Eschenauer GA, Troost JP, Golob JL, Gandhi TN, Wang L, et al. Tocilizumab for treatment of mechanically ventilated patients with COVID-19. Clin Infect Dis. 2020 Jul 11; 73:e445-54.

12 Potere N, Di Nisio M, Cibelli D, Scurti R, Frattari A, Porreca E, et al. Interleukin-6 receptor blockade with subcutaneous tocilizumab in severe COVID-19 pneumonia and hyperinflammation: a case-control study. Ann Rheum Dis. 2020 Jul 9;80:491-8.

13 Antony SJ, Davis MA, Davis MG, Almaghlouth NK, Guevara R, Omar F, et al. Early use of tocilizumab in the prevention of adult respiratory failure in SARS-CoV-2 infections and the utilization of interleukin- 6 levels in the management. J Med Virol. 2020 Jul 9;93:1-2.

14 Quartuccio L, Sonaglia A, McGonagle D, Fabris M, Peghin M, Pecori D, et al. Profiling COVID-19 pneumonia progressing into the cytokine storm syndrome: results from a single Italian Centre study on tocilizumab versus standard of care. J Clin Virol. 2020 May 15 129:104444.

15 Price CC, Altice FL, Shyr Y, Koff A, Pischel L, Goshua G, et al. Tocilizumab treatment for cytokine release syndrome in hospitalized patients with coronavirus disease 2019: survival and clinical outcomes. Chest. 2020 Jun 15; 158:1397-408.
16 Klopfenstein T, Zayet S, Lohse A, Balblanc JC, Badie J, Royer PY, et al. Tocilizumab therapy reduced intensive care unit admissions and/ or mortality in COVID-19 patients. Med Mal Infect. 2020 Aug;50:397-400.

17 Alattar R, Ibrahim TBH, Shaar SH, Abdalla S, Shukri K, Daghfal JN, et al. Tocilizumab for the treatment of severe coronavirus disease 2019. J Med Virol. 2020 May 5;92:2042-9.

18 Rojas-Marte G, Khalid M, Mukhtar O, Hashmi AT, Waheed MA, Ehrlich S, et al. Outcomes in patients with severe COVID-19 disease treated with tocilizumab: a case-controlled study. QJM. 2020 Aug 1;113:546-50.

19 Pérez-Sáez MJ, Blasco M, Redondo-Pachón D, Ventura-Aguiar P, Bada-Bosch T, PérezFlores I, et al. Use of tocilizumab in kidney transplant recipients with COVID-19. Am J Transplant. 2020 Jul 12;20:3182-90.

20 Knorr JP, Colomy V, Mauriello CM, Ha S. Tocilizumab in patients with severe COVID-19: a single-center observational analysis. J Med Virol. 2020 Jun 17;92:2813-20.

21 Campochiaro C, Della-Torre E, Cavalli G, De Luca G, Ripa M, Boffini N, et al. Efficacy and safety of tocilizumab in severe COVID-19 patients: a single-centre retrospective cohort study. Eur J Intern Med. 2020 May 22;76:43-

22 Colaneri M, Bogliolo L, Valsecchi P, Sacchi P, Zuccaro V, Brandolino F, et al. Tocilizumab for treatment of severe COVID-19 patients: preliminary results from SMAtteo COvid19 REgistry (SMACORE). Microorganisms. 2020 May 9;8:695.

23 Stone JH, Frigault MJ, Serling-Boyd NJ, Fernandes AD, Harvey L, Foulkes AS, et al. Efficacy of tocilizumab in patients hospitalized with Covid-19. N Engl J Med. 2020 Oct 21; 383:2333-44.

24 Isaacs JD, Harari O, Kobold U, Lee JS, Bernasconi C. Effect of tocilizumab on haematological markers implicates interleukin-6 signalling in the anaemia of rheumatoid arthritis. Arthritis Res Ther. 2013;15:R204.

25 Hashimoto M, Fujii T, Hamaguchi M, Furu $\mathrm{M}$, Ito $\mathrm{H}$, Terao $\mathrm{C}$, et al. Increase of hemoglobin levels by anti-IL-6 receptor antibody (tocilizumab) in rheumatoid arthritis. PLoS One. 2014 May 30;9:e98202.

26 Matsuyama M, Suzuki T, Tsuboi H, Ito S, Mamura M, Goto D, et al. Anti-interleukin-6 receptor antibody (tocilizumab) treatment of multicentric Castleman's disease. Intern Med. 2007 Jun 1;46:771-4.

27 Kremer JM, Blanco R, Brzosko M, BurgosVargas R, Halland A-M, Vernon E, et al. Tocilizumab inhibits structural joint damage in rheumatoid arthritis patients with inadequate responses to methotrexate: results from the double-blind treatment phase of a randomized placebo-controlled trial of tocilizumab safety and prevention of structural joint damage at one year. Arthritis Rheum. 2011 Mar; 63:609-21.
28 Emery P, Keystone E, Tony HP, Cantagrel A, van Vollenhoven R, Sanchez A, et al. IL-6 receptor inhibition with tocilizumab improves treatment outcomes in patients with rheumatoid arthritis refractory to anti-tumour necrosis factor biologicals: results from a 24 -week multicentre randomised placebo-controlled trial. Ann Rheum Dis. 2008 Nov;67:1516-23.

29 Cavezzi A, Troiani E, Corrao S. COVID-19: hemoglobin, iron, and hypoxia beyond inflammation. A narrative review. Clin Pract. 2020 May 19;10:1271.

30 Centers for Disease Control and Prevention. Overview of testing for SARS-CoV-2 (COVID-19)/CDC [Internet] [cited 2020 Sep 29]. Available from: https://www.cdc.gov/ coronavirus/2019-ncov/hcp/testing-overview.html.

31 Nemeth E, Ganz T. Anemia of inflammation. Hematol Oncol Clin North Am. 2014 Aug;28: 671-vi.

32 Parrow NL, Fleming RE, Minnick MF. Sequestration and scavenging of iron in infection. Infect Immun. 2013 Oct;81:3503-14.

33 Auerbach M, Adamson JW. How we diagnose and treat iron deficiency anemia. Am J Hematol. 2016 Jan;91:31-8.

34 Gafter-Gvili A, Schechter A, Rozen-Zvi B. Iron deficiency anemia in chronic kidney disease. Acta Haematol. 2019 Apr 10;142(1):4450.

35 Luo P, Liu Y, Qiu L, Liu X, Liu D, Li J. Tocilizumab treatment in COVID-19: a single center experience. J Med Virol. 2020 Apr 15;92: 814-8.

36 Thursz M. Iron, haemochromatosis and thalassaemia as risk factors for fibrosis in hepatitis C virus infection. Gut. 2007 May;56:613-4.

37 Price L, Kowdley KV. The role of iron in the pathophysiology and treatment of chronic hepatitis C. Can J Gastroenterol. 2009 Dec;23: 822-8.

38 Choy EH, De Benedetti F, Takeuchi T, Hashizume M, John MR, Kishimoto T. Translating IL-6 biology into effective treatments. Nat Rev Rheumatol. 2020 Apr 23;16:335-45.

39 Toniati P, Piva S, Cattalini M, Garrafa E, Regola F, Castelli F, et al. Tocilizumab for the treatment of severe COVID-19 pneumonia with hyperinflammatory syndrome and acute respiratory failure: a single center study of 100 patients in Brescia, Italy. Autoimmun Rev. 2020 Jul;19:102568.

40 WHO Rapid Evidence Appraisal for COVID-19 Therapies (REACT) Working Group; Shankar-Hari M, Vale CL, Godolphin PJ, Fisher D, Higgins JPT, et al. Association between administration of il- 6 antagonists and mortality among patients hospitalized for COVID-19: a meta-analysis. JAMA. 2021 Aug 10;326:499-518.

41 Kawabata H, Tomosugi N, Kanda J, Tanaka Y, Yoshizaki K, Uchiyama T. Anti-interleukin 6 receptor antibody tocilizumab reduces the level of serum hepcidin in patients with multicentric Castleman's disease. Haematologica. 2007 Jun;92:857-8. 
42 Hashizume M, Uchiyama Y, Horai N, Tomosugi $N$, Mihara M. Tocilizumab, a humanized anti-interleukin-6 receptor antibody, improved anemia in monkey arthritis by suppressing IL-6-induced hepcidin production. Rheumatol Int. 2010 May;30:917-23.

43 Song SN, Tomosugi N, Kawabata H, Ishikawa T, Nishikawa T, Yoshizaki K. Down-regulation of hepcidin resulting from long-term treatment with an anti-IL-6 receptor antibody (tocilizumab) improves anemia of inflammation in multicentric Castleman disease. Blood. 2010 Nov 4;116:3627-34.

44 Sasaki A, Yasukawa H, Shouda T, Kitamura T, Dikic I, Yoshimura A. CIS3/SOCS-3 suppresses erythropoietin (EPO) signaling by binding the EPO receptor and JAK2. J Bio Chem. 2000 Sep 22;275:29338-47.
45 Nairz M, Haschka D, Demetz E, Weiss G. Iron at the interface of immunity and infection. Front Pharmacol. 2014 Jul 16;5:152.

46 Georgiou NA, van der Bruggen T, Oudshoorn M, Nottet HS, Marx JJ, van Asbeck BS. Inhibition of human immunodeficiency virus type 1 replication in human mononuclear blood cells by the iron chelators deferoxamine, deferiprone, and bleomycin. J Infect Dis. 2000 Feb;181:484-90.

47 Cinatl J, Cinatl J, Rabenau H, Gümbel HO, Kornhuber B, Doerr HW. In vitro inhibition of human cytomegalovirus replication by desferrioxamine. Antiviral Res. 1994 Sep;25:737.
48 Dalamaga M, Karampela I, Mantzoros CS. Commentary: could iron chelators prove to be useful as an adjunct to COVID-19 treatment regimens? Metabolism. 2020 May 8;108: 154260 .

49 Abobaker A. Reply: iron chelation may harm patients with COVID-19. Eur J Clin Pharmacol. 2020 Sep 1;77:267-8.

50 Visseren F, Verkerk MS, van der Bruggen T, Marx JJ, van Asbeck BS, Diepersloot RJ. Iron chelation and hydroxyl radical scavenging reduce the inflammatory response of endothelial cells after infection with Chlamydia pneumoniae or influenza A. Eur J Clin Invest. 2002 Mar;32 Suppl 1:84-90.

51 Garrick MD, Ghio AJ. Iron chelation may harm patients with COVID-19. Eur J Clin Pharmacol. 2020 Sep 1;77:265-6. 